\title{
Exclusão digital e fotografia: apropriações e utilizações dos equipamentos de captação da imagem
}

\section{DANIEL MEIRINHO DE SOUZA}

\section{Resumo}

O objeto deste artigo parte das relações criadas entre os indivíduos e as tecnologias digitais de captação fotográfica. É desenvolvido um entendimento sobre os avanços, as transformações e a popularização que a fotografia tem sofrido, até chegar a uma alargada acessibilidade. Com base no levantamento de dados recolhidos a partir de uma amostra sistemática de entrevistas realizadas por investigadores de Lisboa, Coimbra e Porto, para o projeto de investigação "Inclusão e participação digital”, esta análise procura compreender as apropriações e utilidades dadas à imagem fotográfica e aos equipamentos de captação imagética por parte dos indivíduos entrevistados, incluindo a utilização e captação da fotografia gerada pelos celulares como ferramenta digital, as suas especificações e características, e a relação que a fotografia possui com a memória e o registro, enquanto função social.

Palavras-chave: Fotografia, inclusão digital, celulares 


\title{
Photography and digital exclusion: appropriations and uses of image capture equipment
}

DANIEL MEIRINHO DE SOUZA

\begin{abstract}
The purpose of this article part of relations established between individuals and the technologies of digital photo capture. It developed an understanding of the advances, changes and popularization that photography has to suffer, until you reach a wider accessibility. Based on survey data gleaned from a systematic sample of interviews conducted by researchers from Lisbon, Coimbra and Porto, for the research "Digital Inclusion and Participation", this analysis seeks to understand the uses and appropriations given to the photographic image and equipment to capture imagery from individuals interviewed, including the use and collection of photographys generated by mobile phones as digital tool, its specifications and features, and the relationship that photography has with memory and registration as a social function.
\end{abstract}

Keywords:

Photography, digital inclusion, mobile phones and memory 


\section{Introdução}

O "fosso digital" em que se encontram algumas parcelas sociais passa a intensificar-se como objeto de interesse político e acadêmico a partir da década de 90 (SELWYN, 2006). No início do século XXI, alguns entusiastas tecnológicos, como Strover (2003) e Compaine (2001), declararam a exclusão digital como vencida, ou pelo menos em vias de extinção. No entanto, a equidade de acesso ainda está longe de ser alcançada. São gritantes as desigualdades criadas pela tecnologia, sendo esta uma barreira limitadora entre os que estão imersos no conhecimento e os que dele se encontram excluídos. É possível crer que os alicerces para a compreensão do "fosso digital"1 passam pelo entendimento entre inclusão e exclusão digital e o seu grau de correlação com a exclusão social. Jung (2001), na sua pesquisa, ressalta que a exclusão digital pode ser apenas uma característica superficial, que mascara as desigualdades sociais mais importantes. Entendemos que a partir da condição de acesso poderemos obter uma das diversas variáveis que condicionam a compreensão, de forma mais analítica, das problemáticas de desigualdade e "marginalidade" social.

Desenvolvemos um entendimento sobre os avanços, as transformações e a popularização que a fotografia tem vindo a sofrer, até chegar a uma alargada acessibilidade. O seu baixo custo, as melhores condições para aquisição de equipamentos, bem como a sua agregação a outros aparelhos como celulares e PDAs, mostram a função híbrida que a fotografia têm vindo a assumir no campo tecnológico. A fotografia digital, hoje, apresenta mudanças radicais através da imediata visualização da imagem, dos menores custos de produção, além de uma grande facilidade em manipular, editar e difundir a imagem. Em poucas palavras, a fotografia ganha um novo suporte que a populariza e a torna mais presente na vida cotidiana das pessoas. 
Este artigo é constituído por um enquadramento teórico, no sentido de identificar qual o ponto de situação referente às pesquisas nas áreas da fotografia e inclusão digital realizadas no mundo. Uma reflexão teórica fundamentada serve como base estrutural para a análise empírica. As orientações metodológicas são os pontos norteadores para traduzir as motivações que levaram ao propósito deste trabalho.

\section{A fotografia como ferramenta tecnológica}

É pelo fato da sociedade atual se encontrar em contato direto com algumas tecnologias que propomos analisar as transformações e influências de uma, em específico: a fotografia. Partimos do pressuposto de que, com os avanços tecnológicos no campo imagem fotográfica, esta se torna parte integrante das relações interpessoais, pois nela estão eternizados recortes de momentos que não se poderão repetir, existencialmente.

A partir do instante em que a fotografia é analisada como uma tecnologia, através da sua popularização, a imagem fotográfica torna-se uma influência crescente nas relações com pessoas, objetos, conhecimento e a imaginação de cada indivíduo. É verdade que tal situação pode ser observada com a pintura, antes do surgimento da daguerreotipia ${ }^{2}$, no século XIX. Entretanto, nunca seria tão divulgada e acessível como na era digital. $O$ fato é que a imagem fotográfica tem vindo a passar por uma transformação radical na sua função social na vida cotidiana (BOURDIEU, 1965).

\subsection{As transformações referentes à função so- cial da fotografia}

A fotografia transgride o poder temporal e simbólico e assume um papel de representação de momentos, lugares, objetos e lembranças de bons tempos. Carole Rivière (2006) apresenta ideias distintas quando afirma que a função da fotografia, particularmente a de registro familiar, não desaparece com avanços tecnológicos, mas se altera. Sobre a sua função, assume que "têm gradualmente alargado a prática de situações fotográficas cada vez mais diversificadas, profanado o seu uso, até agora reservado para momentos excepcionais" (RIVIĖRE, 2006, p.120). Van House (2005) confirma a teoria quando diz que "com uma câmara sempre disponível e com fácil visualização e partilha de fotografias, as pessoas têm encontrado novas formas de usar as imagens 
para suportar usos sociais. Formas estas não utilizadas anteriormente." (VAN HOUSE et al., 2005, p.1856).

Um dos processos mais significativos de avanços e transformações que a fotografia viveu ao longo da sua história, mais ainda do que a invenção da Kodak por George Eastman ${ }^{3}$ ou a migração do analógico para o digital, tem sido a associação da fotografia a outros dispositivos como o celular. Tal situação pode ser verificada pela relação de extensão do corpo e situação de domesticação e dependência que os celulares assumem na sociedade atual. A função de obtenção da imagem fotográfica pelo dispositivo telefónico concretiza o sonho de uma câmera portátil, que qualquer pessoa pode levar para qualquer lugar, mas que não apresente apenas um único recurso: a de captação fotográfica. Os indivíduos que precisavam carregar um equipamento fotográfico, ao sair de casa, agora estão munidos do aparato constantemente.

A popularização da coleção de imagens da vida cotidiana tornou-se realidade com a Kodak, em 1889. Com o slogan You press the button, we do the rest ${ }^{4}$, Eastman transformou o ato fotográfico num ato fácil, popular e sem necessidade de técnicas e conhecimentos mais avançados. No entanto, hoje em dia, segundo Rivière (2006), a imagem fotográfica alcançou um nível ainda maior de acesso e reprodução com as câmeras acopladas aos celulares. Desta forma, a popularidade dos equipamentos fotográficos, para captar momentos domésticos e habituais, atinge o seu apogeu. A autora vai mais além quando diz que "o 'telefone móvel' é o primeiro estado, a prótese da pessoa” (RIVIÈRE, 2006, p.121). Assim, comenta que o celular conduz a um efeito de banalização do ato de fotografar, permitindo às pessoas fazê-lo diariamente, a qualquer hora e de qualquer maneira.

A autora aponta ainda que a utilização da fotografia pelos celulares constitui uma mudança fundamental na função social da fotografia. A autora afirma que as fotos ou vídeos captados pelos telefones não são produzidos para marcar a memória, para imprimir ou guardar álbuns. Segundo a pesquisadora, existem concepções distintas entre a fotografia tradicional e a gerada por telefone.

Esta divergência não se trata de eternizar o momento e recordar os laços sociais, mas de circular na rede, através dos envios rápidos e imediatos. É trocar com o outro, pela rede, ou mesmo mostrar diretamente para quem está ao lado o "veja essa foto que fiz agora”, ou como diz Rob Shields (2003): “olha! É nos 5 segundos atrás!". O que importa, como explica Rivière, é marcar o presente banal e não os momentos especiais e solenes. 
Barbara Scifo (2005) prefere observar este fenômeno de mudança através de um olhar sociológico. Para a autora, o ato de fotografar transformou-se com o telefone em algo lúdico e não banal. Uma essência quase mágica, onde acontece um jogo de capturar imagens e partilhar com amigos.

Estudos feitos no Japão, Finlândia, França e Itália (KOSKINEN, 2004; KATO, OKABE et al., 2005; RIVIÈRE, 2005; ROUCHY, 2005; SCIFO, 2005; GOGGIN, 2006) mostram que a maior parte dos utilizadores de câmaras fotográficas pelos celulares não fazem, ou não se preocupam em fazer, um backup do material visual produzido. Os utilizadores enviam as fotografias a amigos ou usam-nas como fundo de tela do aparelho, sem a preocupação de guardar estas imagens como memória. Neste caso, a difusão imagética é feita de forma diferenciada daquela usual de arquivar as imagens em álbuns.

Tomamos como exemplo um dos diversos estudos publicados sobre a utilização e função da imagem fotográfica gerada por celulares. Uma pesquisa feita em 2003, no Japão, com jovens e adolescentes aponta que as fotografias digitais captadas pelos celulares faziam parte de um processo de socialização e eram compartilhadas, apenas, com as pessoas mais íntimas do círculo de amizades. Okabe (2004) diferencia estas das obtidas por uma câmera fotográfica tradicional. Através do estudo, o investigador observa que as imagens num telemóvel são de curta duração e mais efémeras. Podem ser tiradas para compartilhar um momento com alguém e depois serem apagadas. Situação contrária é registrada com fotografias feitas com uma câmera fotográfica, por exemplo, de turista ou profissional, onde as imagens são feitas com a finalidade de serem arquivadas. "Os telefones com câmera alteram a definição de que a fotografia é especial e duradoura, para transitórias e ordinárias" (VAN HOUSE et al., 2005, p. 1854).

Scifo (2005), no seu estudo, apresenta uma visão distinta. Para a investigadora italiana, as fotografias geradas por telefone não apresentam o caráter de curta duração, mas continuam a ter a função de registro. $\mathrm{O}$ dispositivo telefônico até potencializa o acesso ao arquivo. "A câmera do telefone também funciona bem como um arquivo fotográfico de memórias, um arquivo dentro dos celulares de fácil alcance. Algo para olhar repetidamente" (SCIFO, 2005, p.365).

Apesar de a investigação de Okabe ter sido desenvolvida há oito anos - muito tempo quando falamos de inovações e domesticação tecnológica - e no Japão, que apresenta um contexto social, econômico e cultural bastante diferenciado, não sendo possível uma comparação direta com a pesquisa proposta neste artigo, é importante perceber que os indivíduos estão a utilizar a convergência digital dos 
celulares nas suas relações sociais. Mesmo os jovens japoneses, no estudo Uses and Possibilities of the Keitai Camera, assim como os nossos entrevistados ao compartilharem fotografias de algum acontecimento do dia, passam a interagir com seus familiares e amigos através das imagens captadas.

A partir da sua funcionalidade como registro do real, a imagem fotográfica assume uma função social de tornar eternos os momentos, sejam estes de reunião social ou familiar, pela captação de momentos solenes e para reforçar a integração do grupo familiar. Existe claramente a intenção do registro que reforçará a memória através do arquivo, no que Bourdieu (1965) chamava de "verdade da lembrança" e Barthes (1980) de "ratificação do passado". A prática também requisitava o momento solene, o tempo de revelação do filme e a documentação em álbuns. É com o regresso ao álbum, dos momentos familiares (volta ao passado), que a fotografia consegue reforçar a memória individual e coletiva.

\subsection{Fotografia e memória}

Com a evolução dos processos e a popularização da fotografia, os retratos em família passam a ser produzidos sem a presença de um profissional, permitindo que os familiares produzam as suas fotografias e os seus álbuns, perpetuando assim, mais eficazmente, uma memória secular. Bourdieu (1965) evidencia o significado do "álbum de família", quando afirma:

A galeria de retratos democratizou-se e cada família tem, na pessoa do seu chefe, o seu retratista. Fotografar as suas crianças é fazer-se historiógrafo da sua infância e preparar-lhes, como um legado, a imagem dos que foram... O álbum de família exprime a verdade da recordação social. (BOURDIEU, 1965, p.53-54).

Para fundamentarmos melhor a função que a fotografia possui como objeto de memória, partimos do pressuposto de que a fotografia apresenta e representa um real reproduzido de um determinado recorte do tempo e do espaço. Se constatarmos que a imagem fotográfica é a revelação de um olhar que observa um determinado momento histórico, pode ser apresentada como realizadora da construção e produção da memória, sendo essa representada pela imagem. A reconstituição, seja de recordação pessoal ou histórica, irá provocar um processo de (re)criação de realidades.

Historicamente, a fotografia passa a ser o suporte 
ideológico para uma representação "perfeita" do real que o homem moderno perseguia desde a Antiguidade. Esta imagem transforma-se num elemento referencial da ação, caracterizando uma lembrança provocada pelo olhar que vê e uma síntese da memória pessoal de cada indivíduo. A partir dessa lembrança, são construídas redes de significados precisos que singularizam a rememoração pelo ato emocionado. Esta provoca no observador, a partir da cumplicidade estabelecida entre ele e a imagem, a sensação de que aquele momento já não existe, mas que é permanente na realidade da fotografia.

Segundo Pollak (1992), a memória é constituída por acontecimentos, por pessoas/personagens e por lugares. "Existem lugares da memória, lugares particularmente ligados a uma lembrança, que pode ser uma lembrança pessoal, mas também pode não ter apoio no tempo cronológico" (POLLAK, 1992, p. 2).

Dubois (1984) afirma ainda que "a memória é feita de fotografias" (DUBOIS, 1984, p. 314-317), sendo a imagem fotográfica, portanto, uma das formas modernas que melhor encarna o prolongamento das artes da memória. Dubois salienta também que a memória pode ser entendida como uma máquina, feita de câmera (os lugares) e de revelações (as imagens).

O fato é que a fotografia historicamente foi - e continua a ser - um fenômeno que revolucionou a memória, a sociedade da época e o pensamento moderno. A concepção e visão de mundo alteraram-se a partir do seu advento com a sua chamada visão imparcial, precisa, metódica, inequívoca, que muito contribuiu nos campos da evolução tecnológica, informativa, dedutiva, historiadora do campo social.

Este é o grande valor pertencente à fotografia. Com razão, Le Goff (2003) afirma que esta "revolucionou a memória" pois, de imediato, a fotografia pode ativar a memória, falar sobre um passado, permitir revivê-lo no presente, mesmo não sendo pertencente ao indivíduo que a observa, mesmo não sendo até a rememoração de seu passado.

\section{Fundamentos metodológicos para a análise dos dados}

Com a finalidade de tentar esclarecer algumas questões que rondam a fotografia e com base na teoria propostas relativamente à sua função social e a relação criada com os seus utilizadores, 
sugerimos algumas questões para análise. Entre elas: Para quem fotografa, existem diferenças entre captar uma realidade a partir de dispositivos distintos? É possível afirmar que a fotografia está a passar por uma transformação da sua função social com a migração para o digital? A fotografia promove laços familiares e de integração social? Se sim, existe uma relação entre a imagem fotográfica, as recordações e lembranças das pessoas? O que muda com as tecnologias digitais de captação da imagem fotográfica? Quais são as variáveis que marcam as relações de apropriação entre os indivíduos e a fotografia?

Como suporte para responder a estas questões, procuramos uma análise mais detalhada das entrevistas a 65 famílias residentes em Portugal, no âmbito do Projeto Inclusão e Participação Digital (2009-2011). Entre as problemáticas a serem trabalhadas pelo Projeto, estão questões voltadas para as desigualdades sociais traduzidas pelas disparidades de acesso e uso das tecnologias por diferentes indivíduos e famílias, tentando estabelecer uma reflexão nas condições, apropriações e naturezas desta utilização e participação.

As entrevistas semi-estruturadas foram desenvolvidas a partir de um questionário aplicado entre os meses de Novembro e Dezembro de 2009, nas cidades portuguesas de Lisboa, Porto e Coimbra. O questionário foi estruturado em duas partes, sendo a primeira com questões voltadas para a história, vivências e trajetórias de vida dos entrevistados e uma segunda com perguntas relacionadas com as utilizações, apropriações, condições de acesso e uso dos mídia digitais. Foram inquiridos dois membros da mesma família de diferentes gerações.

Após a realização das entrevistas, iniciamos a análise e leitura das mesmas. A partir da decomposição, foram cruzados as respostas que mencionam a fotografia com as seguintes variáveis: sexo, idade, estatuto socioeconômico, utilização e apropriação dos equipamentos fotográficos.

Apesar do questionário conter apenas uma única questão diretamente relacionada com fotografia: Tem uma câmara fotográfica ou de filmar? O que costuma fazer habitualmente com ela? Quando era criança, a sua família também tinha estes equipamentos?, existiam outras referências ao ato de fotografar.

Como algumas respostas apontam o uso dos celulares para a captação de fotografias, também achamos necessário incluir as três perguntas relativas ao tema inseridas no inquérito. No entanto, só foram dissecadas as respostas em que os entrevistados comentavam a utilização de recursos fotográficos nos seus celulares. Entre elas estão: Tem celular? Que tipo 
de celular possui, que características tem? Que tipo de utilização lhe costuma dar? E em relação à sua família, quem foi a primeira pessoa na família a ter um celular? (no caso de ser imigrante) Usa o celular para contactar a sua família e amigos? Que outros meios usa para contactar a sua família?

A partir deste contexto, e com estes dados disponíveis para análise, foi feita uma observação analítica com a finalidade de tentar entender as relações existentes entre os entrevistados e a imagem fotográfica. Neste caso, chamaram-nos a atenção as respostas referentes a fotografias obtidas pelos celulares e de que forma esse suporte visual é utilizado como objeto de memória.

\section{Apropriações e utilizações dos equipamentos fotográficos}

Os entrevistados, quando questionados se o equipamento fotográfico ou de filmar estava presente nas suas infâncias, respondem sempre com um saudosismo de um passado que já se foi, mas continua a ser imortalizado graças aos registros fotográficos. Esta é a relação presente entre a fotografia, a lembrança e as memórias de cada indivíduo. Observamos que igualmente os entrevistados, independente do seu estatuto socioeconómico, género e geração, comentam que possuem registros fotográficos arquivados.

Ao tentar-se fazer um perfil básico dos entrevistados, visualizamos que os que possuem menor utilização de dispositivos fotográficos são homens, acima dos 45 anos, com baixa escolaridade. Nestes, as câmeras estão sob encargo, normalmente, dos filhos, netos ou esposa. No ponto referente ao gênero, os membros familiares femininos despontam como utilizadores frequentes dos dispositivos fotográficos. A questão da situação económica e social não é necessariamente um empecilho para obter tais equipamentos. Isso deve-se ao fato do mercado apresentar ofertas acessíveis. Assim, a condição socioeconômica da família pode ser uma variante importante, no que se refere à especificação e funcionalidades do equipamento, mas não à posse destes dispositivos.

\subsection{A fotografia feita por celulares}

Um fato notório, na leitura das entrevistas realizadas, é que quase metade dos entrevistados anunciam já não utilizarem as máquinas fotográficas enquanto aparelho de captação de imagem, sendo este equipamento substituído pela função de câmera fotográfica de alguns celulares. 
"Hoje em dia, quem têm um bom telemóvel já não precisa de uma câmara. Eu tenho um telemóvel. Tem três mega pixels. (...) o meu telemóvel 5 faz fotografias de qualidade como uma máquina de três mega pixels faz. Por isso é que eu não tenho câmara. Tenho lá uma câmara em casa, mas não a uso." (Português e Segurança, 47 anos).

Do total das entrevistas aplicadas, observamos que mais da metade dos entrevistados possuem um celular com o recurso de câmera fotográfica. Destes, quase metade afirmam utilizar a captação fotográfica através do aparelho, contra uma pequena parcela que declara não a usar. Os utilizadores das funções do dispositivo para fotografar são maioritariamente os membros da família mais jovens ou adultos até os 40 anos, com algumas poucas exceções.

As pessoas após os 40 anos mostram-se mais adversas a essas utilizações do seu aparelho de telefone móvel. Esse comportamento pode ser analisado pela idade dos indivíduos decorrente do pouco interesse pela tecnologia. Em certa entrevista, uma senhora de 42 anos, que diz fazer uso assíduo das tecnologias através do computador e da Internet, quando questionada sobre as funções do seu telefone celular, afirma que este apresenta recursos tecnológicos híbridos, mas utiliza-o para a função mais básica que ele proporciona.

"Sei que faz imensas coisas que eu não utilizo, estou a ficar velhinha e nunca utilizei. Sei que dá para gravar Mp3, que tira foto, dá pra filmar, essas coisas. Essencialmente dá pra telefonar. (...) oh, faz isso, têm lá fotos, tem lá filmes, às vezes me pergunto, mas pra que isso?" (Portuguêsa e Secretária, 42 anos).

Não existe uma grande diferença entre os utilizadores com maior ou menor grau de habilitações literárias. Assim, como os que possuem mais ou menos capital cultural, ou até econômico. Com a acessibilidade dos valores de aquisição de celulares com recursos múltiplos em Portugal, mesmo os entrevistados com condições financeiras mais desfavoráveis conseguem ter posse de um aparelho com, pelo menos, a função de câmera fotográfica.

Apesar de metade dos entrevistados afirmar não possuir mais câmeras fotográficas, mencionam fazer fotografias, na mesma, a partir dos seus aparelhos telefônicos. Alguns dizem que a maior parte das utilizações que dão aos celulares é mesmo a de câmera fotográfica. "Quando eu vou a algum lado, tiro uma fotografia para ficar como recordação. Tiro fotografias à minha família para ficar aqui guardado (...) e é essa a utilização do telemóvel." (Português e Estudante, 17 anos). "Hoje 
em dia, quem tem um bom telemóvel já não precisa de uma câmara." (Segurança, 47 anos).

Estudos nesta área, como os de Ling (2004), Castells (2007) e Goggin (2006), comprovam que as funções fotográficas, audição de música e envio de mensagem (SMS e MMS) estão na mesma proporção que a utilização básica do dispositivo, a de fazer ligações.

Enquanto a câmera apenas capta instantes festivos, determinados e pontuais, o celular captura imagens do cotidiano, pois está sempre à mão. Esta análise reforça alguns estudos citados como os de Koskinen (2004), Kato, Okabe et al. (2005), Rivière (2005), Rouchy (2005), Scifo (2005) e Goggin (2006), que apontam para uma mudança na função social da fotografia. A partir das respostas apresentadas, é possível perceber as diferenças entre as fotografias tiradas pelas câmaras fotográficas e as captadas pelas câmeras incorporadas aos telefones. Esses usos e funções distintos são apontados no nosso enquadramento teórico realizado.

"Uma coisa quando eu acho 'bacana' é quando eu estou em algum lugar e me apetece de gravar aquela imagem e eu lembro que eu tenho telemóvel e isso, para mim, é uma das coisas que eu mais gosto da modernidade." (Imigrante brasileiro e Officie Boy, 35 anos)

\subsection{Gênero e imagem}

O grupo de entrevistados mais jovens e, especialmente, do sexo feminino comentam utilizar com mais frequência o recurso fotográfico dos seus celulares. Segundo trabalhos da historiadora brasileira Miriam Moreira Leite (2000), sobre "retratos de família", e da antropóloga Myriam Lins de Barros (1989), sobre "álbuns de família", as mulheres, dentro do grupo familiar e de amigos, assumem o papel de "guardiãs" das memórias familiares e dos seus grupos de relações. Desta forma, podemos dizer que, no aspecto do registro e memória fotográfica, é na adolescência que se inicia uma 'carreira' de responsáveis pelas lembranças e recordações.

Nas entrevistas, também se observa a importância do papel da mãe como retratista e conservadora das lembranças familiares. À matriarca é confiada uma responsabilidade social de preocupação e acompanhamento do crescimento dos filhos, além da preservação, organização, catalogação das fotos e da memória fotográfica da família. Uma imigrante brasileira, que afirma fazer uso assíduo do computador e Inter- 
net, confirma: "A minha mãe era muito adepta a foto, sempre gostou muito e tínhamos muito mesmo. Também, com cinco filhos, não é?" (Imigrante brasileira e Manicure, 42 anos). "Eu adorava tirar fotografias. Antes de mim, a minha mãe adorava tirar fotografias, e antes de eu nascer eles já tinham uma câmara". (Portuguesa e Formadora, 27 anos)

Para Lins de Barros (1989) o guardião da memória "está referido à família quando constrói para si e para os familiares o perfil desse papel social. Não é uma motivação individualizada que leva o coleccionador a procurar, investigar, encontrar e conservar seus bens preciosos. Ele está imbuído de um papel social que lhe confere o direito e também a obrigação de cuidar da memória do grupo familiar" (LINS DE BARROS, 1989, p. 38).

No entanto, é notório que esta função nem sempre foi de responsabilidade do membro feminino da família. Quando os entrevistados são questionados sobre se tinham equipamentos fotográficos na sua infância, referem-se sempre a figa masculina paterna como o "fotógrafo", ou pelo menos o detentor da câmera. Às mulheres, mães, era concebida apenas a responsabilidade de arquivar e manter as recordações guardadas. Um homem, com ensino superior e uso assíduo do computador e Internet, diz: "O meu pai sempre teve uma câmara e, quando saíamos, tirávamos fotografias e sempre tive isso em casa." (Português e Desempregado, 22 anos).

É perceptível uma mudança nos papéis impostos socialmente a quem é determinada uma responsabilidade específica. Nas entrevistas, observamos que atualmente o gênero feminino da família é quem mais frequentemente assume a função de gerador e também conservador das recordações e memórias familiares.

\subsection{Fotografia como objeto de memória}

Um ponto observado na análise é como as fotografias servem de objetos de registro, memória e recordação de ocasiões e momentos especiais como festas, aniversários, férias, etc. Alguns dizem que em momentos de encontros familiares tiravam muitas fotografias e estes são recordados, hoje, graças a este registro. Em certo momento, uma entrevistada, que diz fazer algum uso das tecnologias digitais, descreve: "O meu pai tinha uma máquina fotográfica (...) Temos montes, temos centenas de fotografias que o teu pai tirou". (Portuguesa e Escriturária, 35 anos)

A partir das respostas dos entrevistados, é possível arriscarmos afirmar que tais momentos e memórias passam a não ser gravados nas suas lembranças e recordados se não houver 
um registro. A pesquisadora brasileira, Maria Inez Turazzi (1995), afirma que a fotografia é que credibiliza a veracidade e autenticidade do acontecimento.

Uma entrevistada, que diz fazer raro uso do computador e Internet, quando questionada sobre como são as festas familiares, lembra que logo quando se coloca em um momento "especial", todos já questionam a participação e presença da máquina fotográfica para a geração do arquivo, que apresenta a função futura de rememoração e até afirmação de que dada ocasião existiu: "É pá, a fotografia, é pá a máquina, é pá, vai lá buscar (...) É pá, passou o Ano Novo, nem tirámos uma fotografia.... (Portuguesa e Trabalhadora fabril, 41 anos).

Sobre a veracidade e autenticidade de um fato, Turazzi (1995) afirma que a fotografia é que credibiliza o acontecimento, quando relata que:

A escola histórica filiada ao positivismo, ao transformar os suportes da memória coletiva em documentos com valor de "prova" do tempo passado na história das sociedades, converteu a fotografia - mesmo sem o pretender - em 'testemunho' por excelência da evolução do tempo (TURAZZI, 1995, p. 31).

Neste sentido, pode-se dizer que as possibilidades de lembrança dos momentos diminuem e podem ser apagados por completo das memórias individuais e coletivas caso não exista um registro para recorda-los. Uma senhora com 90 anos exibe ao entrevistador as suas recordações a partir das fotografias emolduradas nos porta-retratos pousados em um móvel da sala. Ela não possui uso assíduo das tecnologias e não menciona as fotografias geradas por celulares, muito menos por equipamentos de captação digital. Para a entrevistada, a imagem fotográfica ainda é algo "palpável" que merece um destaque na casa. "Eu tenho fotografias de todas as maneiras. Olhe, a minha filha, a mãe da Susana, tem lá uma bem bonitinha (referindo-se as fotografias na mesa) num carrinho de bebé quando era pequenina." (Portuguesa e Doméstica, 90 anos).

As fotografias são diversas vezes citadas pelos entrevistados como recordações de momentos "especiais", mas na grande maioria, se não em todas, de ocasiões felizes e nunca tragédias e lembranças tristes. Assim, a imagem fotográfica assume o seu papel artístico e estético de captar o belo, e o seu papel psicossocial de ser uma representação de momentos que valem a pena ser guardados e relembrados. Neste sentido, podemos entender que a memória é o que, na fotografia, 
fica registrado se materializa e se imortaliza. Em certa altura uma mulher, com uso assíduo da internet, comenta: "A gente tirava fotos nos momentos mais importantes da família. Nos encontros, aniversário e essas coisas. (...) sempre utilizei muito a máquina fotográfica. Durante o meu percurso na universidade. Tenho fotografias de quase todos os momentos: testes, aulas, jantares, estudo, noites de estudo.... (Portuguesa e Engenheira do ambiente, 35 anos).

Os entrevistados dizem utilizar mais as câmeras fotográficas e de filmar em determinadas épocas sazonais, festivas e momentos que apresentam uma certa importância nas suas vidas, como Natal, aniversários, fim de ano, férias e verão. Uma jovem, em certa altura comenta: "É mais para o verão, digamos que é mais memórias, que eu nunca vou esquecer, como este verão que nunca vou esquecer, porque tenho tudo gravado". (Portuguesa e Estudante, 15 anos). "Utilizo. Mas é mais no Verão. Assim, no Inverno usa-se quando é aniversários ou Natal. Mas tirando isso, não se usa". (Português e Estudante, 16 anos).

\section{O fim da coletividade do equipamento fotográfico}

Bourdieu (1965) assinala que a câmara fotográfica é considerada a propriedade comum do grupo familiar. Esta acompanha as ocasiões referentes a este grupo, limitada a oportunidades de socialização deste grupo e alguns poucos objetos.

Uma característica observada em relação à utilização dos equipamentos fotográficos e de filmar é a de que, aos poucos, os dispositivos abandonam a sua particularidade de uso familiar para ser um objeto pessoal onde cada membro da família possui o seu. Alguns entrevistados dizem não possuir câmeras fotográficas, mas dizem que os seus pais ou filhos às possuem. O mesmo entrevistado afirma já não precisar de câmera fotográfica, já que o celular substitui as suas funções. Quando questionado pelo entrevistador se possui máquina fotográfica um homem afirma: "Não tenho (...) o meu filho tem uma". (Português e Segurança, 47 anos).

Já uma mulher de 33 anos comprova que não é possuidora do seu equipamento próprio, mas faz utilização da máquina fotográfica dos seus pais. Quando interrogada sobre o mesmo assunto, revela: "Costumo usar uma emprestada que é da minha mãe, mas eu minha não tenho". (Imigrante brasileira e Auxiliar Administrativa, 33 anos). "Temos 3 máquinas fotográficas, uma é minha outra é da minha irmã e outra é da minha mãe". (Portuguesa e Estudante, 16 anos) 
No entanto, as respostas não apontam se o equipamento de captação fotográfica ou de filmar que possuem é digital ou analógico, dificultando uma análise mais específica sobre a especificação do dispositivo.

Essa característica de individualidade do dispositivo também pode ser associada pelas multifunções que os seus celulares possuem e por não sentirem mais a necessidade de aquisição de uma câmera fotográfica tradicional.

\subsection{Outros pontos de análise}

Apesar de o questionário não aprofundar questões mais específicas sobre a relação entre a imagem, os computadores e a Internet, foi possível verificar alguns casos pontuais. Estes referem-se ao computador como uma espécie de "álbum digital" ou arquivo fotográfico. Um homem que trabalha como diretor de empresa de softwares educativos afirma: "Temos também um computador que funciona como um repositório dos conteúdos gerais, das fotografias, portando as coisas que partilhamos". (Português e Director de empresa, 35 anos)

Um jovem universitário, de 22 anos, relata fazer usos frequentes de edição fotográfica a partir de ferramentas informáticas, uploads e downloads de imagens da Internet. "Atualmente, eu tenho uma câmera digital que também filma e eu adoro usar, mesmo para tirar fotos, eu estou sempre actualizando os meus sites, essas coisas e, em viagens, principalmente, o hobby que eu tenho é filmar, fazer um diário da viagem toda e depois editar e colocar na internet". (Imigrante brasileiro e Estudante universitário, 22 anos).

Como a questão referente ao uso de equipamentos fotográficos também abrangia às câmeras de filmar, fizemos uma pequena reflexão. Poucos são os entrevistados que revelam ter. No entanto, a maioria que afirma possuir câmeras de filmar diz que estas estão acopladas como um recurso extra das máquinas fotográficas e dos celulares. Menos de dez entrevistados comentaram ter um dispositivo de captação de vídeo com a única finalidade de filmar. Uma senhora, auxiliar de ação educativa, de 37 anos, afirma: "Tenho máquina de fotografia digital, que dá para tirar fotografias e para filmar. Mas só de filmar, não." (Portuguesa e Auxiliar de educação, 37 anos).

Os membros mais adultos das famílias afirmam que possuíram, em determinada fase da vida, um equipamento de filmar. Lembram com saudosismo da sua utilização. Esta não só relacionada a ocasiões especiais, mas também a fatos dos seus 
cotidianos: "Fazia filmes (risos). Fazia-mos montes de filmes (...) filmar as pessoas na rua (risos) e os cães e não sei porque. O meu pai tinha uma máquina de filmar quando eu era mais miúdo, não sei que idade eu tinha ao certo mas ele tinha. Ele ainda tem algumas coisas nossas. Ele até tem passado algumas coisas para DVD. Volta e meia a gente vê algumas coisas antigas, é engraçado". (Português e Técnico multimédia, 31 anos).

Outros fazem uma associação imediata ao recurso híbrido da sua câmera fotográfica ou a função contida no seu celular. Quando perguntado onde estaria a sua maquina fotográfica um homem de 53 anos afirma: "Nada, está guardada. Estou aqui com o telemóvel”. (Português e Proprietário de um restaurante, 53 anos).

\section{Considerações Finais}

Com as transformações impostas pelos avanços tecnológicos, é perceptível que a imagem passa a assumir um importante papel na comunicação interpessoal. Observa-se que algumas tendências e mudanças nas relações interpessoais se alteram com o surgimento do digital na vida cotidiana das pessoas. Tentamos desta forma responder a questão se "a fotografia promove laços familiares e de integração sócial”. Com o desenvolvimento da análise deste trabalho constatamos que a imagem favorece novas formas de sociabilidade, de laços familiares e sociais já que "seria muito pouco convencional arquivar fotografias de estranhos para um álbum de família" (FROHLICH, 2004, p. 37-38).

Se existe uma relação entre a imagem fotográfica, as recordações e lembranças das pessoas, pode-se afirmar que a memória é um referencial da condição humana e desde sempre o homem se preocupa em deixar marcas da sua existência que um dia lhe darão sentido. Assim, ao promover uma ligação entre um passado que foi registrado e que se reflete na imagem fotográfica, produz-se um efeito de referenciação de momentos que fazem parte da história de cada indivíduo, podendo despertar sentimentos. Seu imaginário trabalha criando uma ilusão intemporal. É como se as suas lembranças retornassem naquele momento e promovessem uma satisfação pessoal através de instantes eternizados pela imagem. Sejam esses momentos positivos ou negativos, sempre serão representados na relação de proximidade que as fotografias têm de trazê-los de volta.

A fotografia, desta forma, passa a ser um suporte perfeito, pois carrega consigo o real retratado por ela e a credibilida- 
de e reafirmação de que aquele momento existiu. O digital só facilita esse processo e o coloca à disposição de uma grande parcela da sociedade.

A sociedade de consumo, regida pela generalização de uma regra de produção de objetos de consumo, impulsiona a novos hábitos e mudanças com a velocidade a que os avanços afetam os indivíduos e os grupos. A acessibilidade e funcionalidade que a telefonia móvel proporciona podem ser um indício dessa economia crescente. Neste contexto, a fotografia acompanha de perto as recentes inovações.

Sobre a questão referente aos novos dispositivos fotográficos digitais, entre eles o celular, sentimos que a imagem fotográfica se insere em uma realidade que já faz parte do cotidiano de muitas sociedades. Podemos vivenciar uma nova forma de abordagem de uma cultura visual, emergente.

Rob Shields (2007) alerta que as imagens, conseguidas através dos celulares, devem ter um entendimento e enquadramento estético e característico, específico do aparelho a partir das suas funções de portabilidade, multifunções, hibridismo, conexão, momento e socialização, pelo olhar rápido e imediato. No entanto, não podemos descartar a relação que a fotografia, obtida pelo telefone, possui com a captada pelas câmeras, que passa pela essência e função que a imagem assume. A relação existente entre a fotografia digital captada pelo dispositivo telefónico e a memória é que ambas servem como tecnologia útil para registro e testemunhas do nosso passado.

É ainda prematuro afirmar que a fotografia passa a assumir um novo papel social com estas novas funções e dinâmicas referentes à tecnologia. No entanto, é evidente que esse processo está em fase de gestação. O seu caráter de mobilidade, portabilidade, popularização e hibridação tecnológica faz com que a imagem atravesse um processo de transformação estrutural, não apenas no seu formato estético, mas na sua função social.

\section{Referências bibliográficas}

BARTHES, Roland. La chambre claire. Note sur la photographie, Paris: Gallimard/Le Seuil, coll, 1980.

BOURDIEU, Pierre. La définition sociale de la photographi", em Pierre Bourdieu, Luc Boltanski, Robert Castel e Jean-Claude Chamboredon, Un Art Moyen: Essai sur les Usages Sociaux de la Photographie, Paris: Les Éditions de Minuit, p. 31-138, 1965.

CASTELLS, Manuel. The Internet Galaxy: Reflections on the In- 
ternet, Business and Society. Oxford: Oxford University Press, 2001.

CASTELLS, Manuel; FERNÁNDEZ-ARDÉVOL, Mireia; LINCHAUN QIU, Jack; SEY, Araba. Comunicacion Movil y Sociedad. Barcelona: Ariel, 2007.

COMPAINE, Benjamin. The Digital Divide: Facing a Crisis or Creating a Myth? Cambridge MA: MIT Press, 2001.

DUBOIS,Phillippe. O Ato Fotográfico e outros ensaios. Campinas: Papirus, 1984.

FROHLICH, David. Audiophotography: Bringing Photos to Life with Sounds. Dordrecht: Kluwer Academic Publishers, 2004.

GOGGIN, Gerard. Cell phone culture: mobile technology in everyday life. Nova York: Routledge, 2006.

GURSTEIN, Michael. Effective use: A community informatics strategy beyond the Digital Divide. In First Monday, v.8, n.12, 2003. Disponível em: <http://firstmonday.org/htbin/cgiwrap/bin/ojs/index.php/fm/article/view/1798/1678>.

Acesso em: 20 de Maio de 2010

JUNG, Joo-Young; QIU, Jack..; KIM, Yong-Chan. Internet Connectedness and Inequality: Beyond the "Divide". Communication Research, v. 28, n. 4, p. 507-535, 2001

KATO, Fumitoshi, OKABE, Daisuke, et al. Uses and Possibilities of the Keitai Camera. In: Okabe, Daisuke e Misa Matsuda (Ed.). Personal, portable, pedestrian: mobile phones in Japanese life. Cambridge, Mass.: MIT Press, 2005.

KODAK. George Eastman. 2010 Disponível em: <http://www. kodak.com/global/pt/corp/historyOfKodak/eastmanTheMan_pt-br.jhtml?pq-path=2217/2687/2689> Acesso em 20 maio 2010

KOSKINEN, Ilpo. Seeing with Mobile Images: Towards Perpetual Visual Contact. Hungarian Academy of Sciences.. Disponivel em: <http://www.fil.hu/mobil/2004/Koskinen_webversion. pdf 2004> Acesso em: 06 de Abril de 2010

LE GOFF, Jacques. História e memória. 5.ed. Campinas: Ed. UNICAMP, 2003.

LEITE, Mirian Moreira. Retratos de Família. 2.ed. São Paulo: Editora da Universidade de São Paulo, 2000

LING, Rich. The Mobile Connection: The Cell Phone's Impact on Society. EUA: Morgan Kaufmann Publishers, 2004.

LINS DE BARROS, Myriam Moraes. Memória e família. Estudos Históricos, n.3, v.2.: Rio de Janeiro. Vértice, 1989, p. 29-42.

OKABE, Daisuke. Emergent Social Practices, Situations and Relations through Everyday Camera Phone Use.. Seul. 2004. p.1819, Disponível em: <http://www.itofisher.com/mito/archives/ 
okabe_seoul.pdf > Acesso em: 6 de Abril de 2010.

POLLACK, Michael. Memória e identidade social. In: Revista Estudos Históricos: Rio de Janeiro, v.5, n.10, 1992, p.200-212.

RIVIÈRE, Carole Anne. Téléphone mobile et photographie : les nouvelles formes de sociabilités visuelles au quotidien, Paris: Sociétés 1, n. 91, 2006, p. 119-134.

RIVIÈRE, Carole Anne. Mobile camera phones: a new form of "being together" in daily interpersonal communication. In: Ling, Richard Seyler e Per E. Pedersen (Ed.). Mobile communications: renegotiation of the social sphere. London: Springer, 2005.

ROUCHY,Philippe. Instant Messaging and Presence Services: Mobile Future, CSCW and Ethnography. In: Hamill, Lynne e Amparo Lasen (Ed.). Mobile world: past, present, and future: New York. Springer, 2005.

SCIFO, Barbara. The Domestication of Camera-Phone and MMS Communication.The Early Experiences of Young Italians. In: Nyíri, Kristóf (Ed.). A sense of place: The global and the local in mobile communication. Viena: Passagen Verlag, 2005.

SELWYN, Neil. The digital divide in the twenty-first century, Poetics, n. 34, p. 273-292, Digital division or digital decision? A study of non-users and low-users of computers: Cardif, 2006.

SHIELDS, Rob, Mobile Phone Imaging as Gesture and Momento. Mobile Nation Conference. 2001 Disponível em: < http:// www.mobilenation.ca/sprshields.html 2007> Acesso em: o6 de abril de 2010.

SHIELDS, Rob. The Virtual. Londres/Nova York: Routledge, 2003

STROVER, Sharon. Remapping the digital divide. The Information Society, no19, 2003, p. 275-277.

TOWNSEND, Abigail. Web belongs to us: how we can shut out spam and join the cyber social club. The Independent on Sunday, Business Section, 2004.

TURAZZI, Maria Inez. Poses e trejeitos: a fotografia e as exposições na era do espetáculo (1839-1889): Rio de Janeiro: Rocco, 1995.

VAN HOUSE, Nancy. et. Al. The Uses of Personal Networked Digital Imaging: An Empirical Study of Cameraphone Photos and Sharing, In: Extended Abstracts of the Conference on Human Factors in Computing Systems, Portland, Oregon. New York: ACM Press, 2005. 
2. O daguerreótipo é uma das primeiras formas de reprodução fotográfica. Deve o nome ao seu inventor, Louis Daguerre, que descreveu pela primeira vez a técnica do daguerreótipo em 1839. No séc. XIX, os daguerreótipos foram muito usados, especialmente para retratos.

3. George Eastman populariza a primeira câmera simples, de fácil manuseio, a milhares de consumidores. Nos anos que se seguiram, particularmente após o lançamento da câmera KODAK e dos métodos simplificados de Eastman, a captura de fotos popularizou-se, com centenas de milhares de amadores. Quando Eastman colocou no mercado seu primeiro filme transparente em rolo, em 1889, criou-se um grande impacto entre consumidores e fotógrafos profissionais.

4. Tradução literal de: "Você aperta o botão, nós fazemos o resto".

5. Termo do Português de Portugal para celular.

Recebido em: 30/07/10

Aceito em: 06/o1/11

\section{DANIEL MEIRINHO DE SOUZA}

danielmeirinho@hotmail.com

É formado em jornalismo, mestre em Comunicação e Artes pela Faculdade de Ciências Sociais e Humanas da Universidade Nova de Lisboa (FCSH/UNL) e doutorando em Comunicação e Ciências Sociais na FCSH/UNL. É investigador do Centro de Investigação Media e Jornalismo (CIMJ) e bolsista da Fundação para a Ciência e Tecnologia (FCT), em Portugal. Faz parte da equipe de pesquisa do Projecto Inclusão e Participação Digital entre a UNL e a The University of Texas at Austin. 